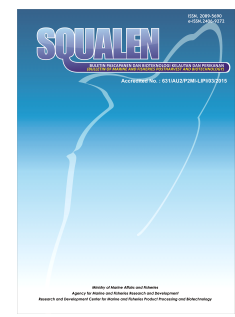

\title{
AMINO ACID AND FATTY ACID COMPOSITIONS OF THE SEA CUCUMBER Stichopus vastus FROM SALEMO ISLAND WATERS, INDONESIA
}

\author{
Abdullah Rasyid \\ Research Center for Oceanography, Indonesian Institute of Sciences \\ Jl. Pasir Putih I Ancol Timur, Jakarta 11048 Indonesia \\ Article history: \\ Received: 2 August 2017; Revised: 15 April 2018; Accepted: 8 May 2018
}

\begin{abstract}
Stichopus vastus is a common commercial sea cucumber in Salemo Island waters, South Sulawesi, Indonesia. However, up to now there are no information regarding to nutritional value, e.g. amino acids and fatty acids of $S$. vastus at this particular location. Different habitat may affect significantly to composition of amino acids and fatty acids. In the present study, the amino acid and fatty acid contents in the sea cucumber $S$. vastus collected from Salemo Island waters Indonesia were determined. Detertmination of amino acid and fatty acid has been conducted using HPLC and GC respectively. Results of this study showed that all essential and non-essential amino acids were found in $S$. vastus. The major essential amino acid content was arginine $(28,651.62 \mathrm{mg} / \mathrm{kg})$, whereas the major non-essential amino acid content was glycine $(60,907.24 \mathrm{mg} / \mathrm{kg})$. The determination of total fatty acids suggested that the saturated fatty acids content was higher than that of polyunsaturated fatty acids and monounsaturated fatty acids. The highest contents of saturated fatty acid, polyunsaturated fatty acid and monounsaturated fatty acid were palmitic acid $(0.07 \%)$, arachidonic acid $(0.13 \%)$ and palmitoleic acid $(0.03 \%)$ respectively.
\end{abstract}

Keyword: amino acid, fatty acid, sea cucumber, Stichopus vastus, Salemo Island

\section{Introduction}

During the past three to four decades, many efforts have been committed to isolating numerous biologically active novel compounds from marine sources. Many of such naturally occurring compounds are of immense interest for potential drug development as well as for ingredients of new leads and commercially successful products for various industrial applications, especially, pharmaceuticals, agrochemicals, functional foods, and nutraceuticals (Venugopal, 2008).

Sea cucumbers (Echinodermata: Holothuroidea) are one of the potential marine animals with high food and medicinal values. In view of the medicinal potential, modern food and pharmaceutical industry is keenly interested to develop some functional foods and nutraceuticals different parts of sea cucumbers (Siddiqui, Arief, Yusoff, Suzina, \& Abdullah, 2013).
Sea cucumbers are marine animals which belong to Phylum Echinodermata and have been used in fresh or dried form in various cuisines. Sea cucumber and its food products are commonly known as bêchede-mer in French, teripang in Indonesian, namako in Japanese, balatan in the Philippines and gamat in Malaysian (Lovatelli \& Conand, 2004). Most cultures in Far East and Southeast Asia consider sea cucumbers as delicacies. The traditional ways of consuming or using sea cucumber vary from one place to another. The body wall is eaten raw in Japan, Samoa and Micronesian, while grilled in Papua New Guinea (Preston, 1993).

Functional food that contains biologically-active compounds is an important source for prevention, management and treatment of chronic diseases in the modern age (Omran, 2013). The ability of the body wall of sea cucumber to regenerate after being cut up reinforced the people's confidence to use as traditional

${ }^{*}$ Corresponding author.

E-mail: a.rasyid.qf@gmail.com 
medicine. Consequently, the body wall of sea cucumber has been use for wound healing especially after clinical surgery and caesarean operation (Fredalina et al.,1999).

The body walls of sea cucumbers is an important source of protein for humans. One of the most important nutritional qualities of protein is amino acid composition (FAO/WHO, 1990). While fatty acids are used as a marker to confirm and trace food resources and trophic relationships in different aquatic habitats (Penha-Lopes, Torres, Narciso, Cannicci, \& Paula, 2009). It is believed that the fatty acids content varies among the sea cucumbers species (Ridzwan et al., 2014). In addition, fatty acids are essential for life due to their positive impact on human health as sources of polyunsaturated fatty acids are being pursued where marine organisms increasingly regarded as good alternative (Santos et al., 2015).

Even there are plenty studies about the composition of amino acids and fatty acids in Stichopus vastus, there are no scientific information about the nutritional value of $S$. vastus from Salemo Island waters, South Sulawesi, Indonesia. Different habitat may affect significantly to composition of amino acids and fatty acids (Al Azad, Shaleh, \& Siddiquee, 2017) and affect the nutritional value. Based on above, this study aimed to determine the amino acid and fatty acid content in sea cucumber $S$. vastus from Salemo Island waters, South Sulawesi, Indonesia. Information regarding those composition will provide the nutritional information of this species from this particular location.

\section{Materials and Methods}

\subsection{Materials}

Six fresh samples of sea cucumber $S$. vastus (Figure 1) were collected from the Salemo Island waters, South Sulawesi, Indonesia on May 2016 by snorkelling and hand collection from shallow reef flat areas. All samples were combined, dissected to remove internal organs, and packed in ice immediately before sending to the laboratory. Samples were kept in $-20 \stackrel{\circ}{ } \mathrm{C}$ until extracted. The taxonomic identification of the samples was carried out by Professor Prapto Darsono from the Research Center for Oceanography, Indonesian Institute of Sciences. Voucher specimen (MA1601) was deposited at $-20^{\circ} \mathrm{C}$ in the Marine Natural Product Laboratory, Indonesian Institute of Sciences.

\subsection{Amino Acid Analysis}

Sample and standard solutions preparation for amino acid analysis was carried out based on literature methods (Waters, 2012). Determination of amino acid by UPLC using chromatography condition as follow : Column (AccQ.Tag Ultra C18 $1.7 \mu \mathrm{m}(2.1 \times 100 \mathrm{~mm})$, Waters); temperature $\left(49^{\circ} \mathrm{C}\right)$; mobile phase (mobile phase $\mathrm{A}=$ Eluent $\mathrm{A}$ Concentrate $\mathrm{Acc} Q \mathrm{Taq}$ Ultra from Waters (Part No. 186003838), mobile phase $B=10 \%$ mobile phase $D$, mobile phase $C=$ Aquabidest and mobile phase $D=$ Eluent $B$ AccQ Taq Ultra from Waters (Part No. 186003839$)$; flow rate $(0.5 \mathrm{ml}$ per minute); detector (PDA, wavelength $260 \mathrm{~nm}$ ) and injection volume $(1 \mu \mathrm{L})$.

Sample preparation: Accurately $0.1 \mathrm{~g}$ sample was weighted, added $5 \mathrm{ml} \mathrm{HCl} 6 \mathrm{~N}$ and then vortexed. The mixture was hydrolysed for 22 hours at temperature $110 \stackrel{\circ}{ } \mathrm{C}$. The hydrolysed mixture was subsequently cooled down and transferred into volumetric flask 50 $\mathrm{ml}$ and diluted to volume with aquadest. The solution was filtered with $0.45 \mu \mathrm{m}$ filter. The $500 \mu \mathrm{L}$ of filtrate was added $40 \mu \mathrm{LAABA}$ and $460 \mu \mathrm{L}$ aquabidest. The $10 \mu \mathrm{L}$ of solution was added $70 \mu \mathrm{L}$ AccQ Fluor Borate and $20 \mu \mathrm{L}$ reagent fluor $\mathrm{A}$ and then vortexed during 1 minute. The solution was Incubated during 10 minutes at $55^{\circ} \mathrm{C}$ and then injected into UPLC system.

Standard solution preparation: The $40 \mu \mathrm{L}$ of standard solution was mixed of amino acid. The 40 $\mu \mathrm{L}$ internal standard AABA and $920 \mu \mathrm{L}$ aquabidest were added and then homogenized. The $10 \mu \mathrm{L}$ of standard solution was pipetted and $70 \mu \mathrm{LAccQ}$ Fluor

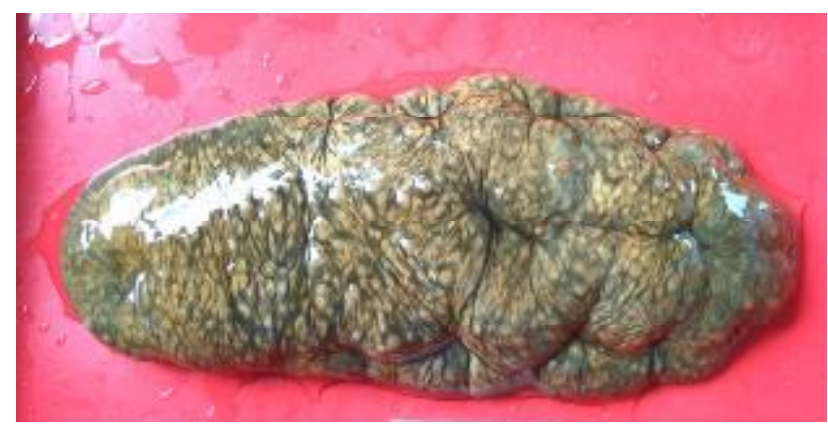

Figure 1. Fresh sea cucumber Stichopus vastus from Salemo Island. 
Borate was added and then vortexed. The $20 \mu \mathrm{L}$ of reagent fluor $A$ was added and vortexed. It was allowed for 1 minute. The solution was incubated for 10 minutes at $55^{\circ} \mathrm{C}$ and injected into UPLC system.

Calculation of the amino acids component $(\mathrm{mg} /$ $\mathrm{kg}$ ) in the sample:

Standard area/Standard AABA $x$ volume of flask $(\mathrm{ml}) \times$ dilution factor $\times$ Standard Concentration.

$$
=\frac{\text { Sample Area } / \text { AABA } \times g \text { sample }}{\text { (m) }}
$$

\subsection{Fatty Acid Analysis}

Fatty acid profile analysis with gas chromatography (Perkin Elmer Clarus 580 GC) using apparatus condition: Column (Supelco SPTM 2560 $100 \mathrm{~m} 0.25 \mathrm{~mm} 0.2 \mu \mathrm{m})$; flow rate $(18.0 \mathrm{~cm} / \mathrm{sec}$ with column length $100 \mathrm{~m})$; carrier gas $\left(\mathrm{N}_{2}\right)$ detector FID $(240 \stackrel{\circ}{\circ})$; injector temperature $\left(225^{\circ} \mathrm{C}\right)$ and split (1:100).

Sample preparation for fat extraction (AOAC, 2000): Accurately $5 \mathrm{~g}$ of sample was weighted and added $4 \mathrm{~mL}$ of isopropanol and then was shaken for 1 minute. Into the solution, $6 \mathrm{~mL}$ of $\mathrm{n}$-hexane was added then vortexed for 1 minute. The solution was subsequently centrifuged for 3 minutes at 9000 RPM. The clear upper solution was moved into a Hach tube and was dried in a water bath. Approximately, $0.03-$ $0.04 \mathrm{~g}$ of the fat extract was weighted and added 1.5 $\mathrm{mL} \mathrm{KOH}$ methanol $0.5 \mathrm{M}$. The solution was heated in a water bath at $100{ }^{\circ} \mathrm{C}$ for 20 minutes and then cooled. Subsequently, $1.5 \mathrm{~mL}$ of $\mathrm{BF}_{3} 20 \%$ in methanol was added. The solution was heated in a water bath at $100^{\circ} \mathrm{C}$ for 20 minutes. The solution was cooled down to $30^{\circ} \mathrm{C}$ while shaken. Accurately $3 \mathrm{~mL}$ of saturated $\mathrm{NaCl}$ was added into the solution and was vortexed for 2 minutes. Subsequently, $0.2 \mathrm{~mL}$ of $\mathrm{n}$-hexane was added into the mixture and was vortexed for 2 minutes. It was allowed to stand at room temperature for 10 minutes. The resulting $n$-hexane methyl ester layer was transferred into $10 \mathrm{~mL}$ volumetric flask, diluted with n-hexane and injected to GC. Calculation of the fatty acids component in the sample: \% fatty acid component in the sampel $=\%$ fatty acid component $x \%$ total fat.

\section{Result and Discussion}

All essential amino acids (histidine, threonine, valine, isoleucine, phenylalanine, leucine, methionine, cysteine, lysine, tryptophan and arginine) and nonessential amino acids (alanine, glutamic acid, serine, proline, tyrosine, aspartic acid and glycine) were found in the sea cucumber $S$. vastus. The major essential amino acid content in the sample of $S$. vastus was arginine $(28,651.62 \mathrm{mg} / \mathrm{kg})$. All essential amino acids were present in relatively high levels, except for cysteine which showed low. The second major essential amino acid was threonine $(16,963.45 \mathrm{mg} /$ $\mathrm{kg}$ ), followed by leucine, phenylalanine, valine, isoleucine, lysine, methionine, histidine, tryptophan and cysteine found to be $11,557.97 \mathrm{mg} / \mathrm{kg}, 10,207.86$ $\mathrm{mg} / \mathrm{kg}, 8,672.02 \mathrm{mg} / \mathrm{kg}, 7,291.89 \mathrm{mg} / \mathrm{kg}, 3,879.20$ $\mathrm{mg} / \mathrm{kg}, 3,802.67 \mathrm{mg} / \mathrm{kg}, 3,434.90 \mathrm{mg} / \mathrm{kg}, 1,644.14$ $\mathrm{mg} / \mathrm{kg}$ and $783.86 \mathrm{mg} / \mathrm{kg}$ ) respectively (Table 1 ).

The major non-essential amino acid content in the sample of $S$. vastus was glycine found to be $60,907.24$ $\mathrm{mg} / \mathrm{kg}$. The result of other non-essential amino acids, including alanine, glutamic acid, serine, proline, tyrosine, aspartic acid and glycine were 26,025.54 $\mathrm{mg} / \mathrm{kg}, 34,015.04 \mathrm{mg} / \mathrm{kg}, 12,844.36 \mathrm{mg} / \mathrm{kg}, 8,790.53$ $\mathrm{mg} / \mathrm{kg}, 18,897.26 \mathrm{mg} / \mathrm{kg}$ and $60,907.24 \mathrm{mg} / \mathrm{kg}$, respectively (Figure 2 ).

Glycine was found the major non-essential amino acids in the present study, similar to that of Actinopyga mauritiana, Holothuria scabra, Bohadschia marmorata and $H$. leucospilota (Omran, 2013), Stichopus herrmanni, Thelenota ananas, T. anax, H. fuscogilva, $H$. fuscopunctata, A. mauritiana, $A$. caerulea and $B$. argus (Wen, Hu, \& Fan, 2010), $H$. arenicola and $A$. mauritiana (Haider et al., 2015), $H$. tubulosa and $H$. polii (Sicuro et al., 2012). It has been known that glycine is used to help create muscle tissue and convert glucose into energy (Omran, 2013). Glycine is also reported essential to maintain central nervous and digestive systems healthy and also has been shown to provide protection some types of cancer via antioxidants (Yahyavi et al., 2012). Glycine can be used not only for treatment of inflammation but also for chemoprevention and treatment of carcinoma (Ridzwan et al., 2014). Additionally it has been shown that glycine reduce levels of total cholesterol in serum (Wen et al., 2010).

According to Bingham (1977), the essential amino acids most often limiting in sea cucumbers are lysine, methionine, threonine and tryptophan. Lysine was the limiting essential amino acid reported in this study, similar to that in eight dried sea cucumbers, i.e. Stichopus herrmanni, Thelenota ananas, T. anax, Holothuria fuscogilva, $H$. fuscopunctata, Actinopyga mauritiana, A. caerulea and Bohadschia argus that were investigated by Wen et al. (2010). Methionine was the limiting essential amino acid reported in this study, similar to that in Parastichopus californicus (Bechtel, Oliveira, Demir, \& Smiley, 2013), Holothuria arenicola and Actinopyga mauritiana (Haider et al. (2015) and Wen et al., 2010). Tryptophan was the 
Table 1. Amino acid composition of fresh sea cucumber Stichopus vastus

\begin{tabular}{rlc}
\hline No & \multicolumn{1}{c}{ Parameter } & Result $(\mathbf{m g} / \mathbf{K g})$ \\
\hline \multicolumn{2}{c}{ Essential amino acids } & \\
1 & Histidine & $3,434.9$ \\
2 & Threonine & $16,963.45$ \\
3 & Valine & $8,672.02$ \\
4 & Isoleucine & $7,291.89$ \\
5 & Phenylalanine & $10,207.86$ \\
6 & Leucine & $11,557.97$ \\
7 & Methionine & $3,802.67$ \\
8 & Cysteine & 783.86 \\
9 & Lysine & 3879.2 \\
10 & Tryptophan & $1,644.14$ \\
11 & Arginine & $28,651.62$ \\
& Non-essential amino acids & \\
12 & Alanine & $26,025.54$ \\
13 & Glutamic acid & $34,015.04$ \\
14 & Serine & $12,844.36$ \\
15 & Proline & $23,605.15$ \\
16 & Tyrosine & $8,790.53$ \\
17 & Aspartic acid & $18,897.26$ \\
18 & Glycine & $60,907.24$ \\
19 & Lycine/Arginine & 0.14 \\
\hline
\end{tabular}

limiting essential amino acid reported in this study, similar to that in H. scabra (Sroyraya et al., 2017). Cysteine was the limiting essential amino acid reported in this study, similar to that in $H$. scabra (Sroyraya et al., 2017). Histidine was also the limiting essential amino acid reported in this study, similar to reported in $P$. californicus (Bechtel et al., 2013) and in S. herrmanni, T. ananas, T. anax, $H$. fuscogilva, $H$. fuscopunctata, A. mauritiana, A. caerulea and $B$. argus (Wen et al. (2010). Apparently, the variation of amino acid content in sea cucumber depends on the species and geographic location.

Considering their effect on quality the final product, amino acid composition was necessary investigated. Amino acids are not only protein constituents. In the free form, amino acids give rise to sweetness, bitterness, sourness and umami taste particularly glutamic acid, which is responsible for the distinctive flavor and taste in various foods. Thus, the composition of free amino acids can significantly influence the quality of marine foods (Sicuro et al., 2012). The presence of high quality of glutamic acid in $S$. vastus could have a positive effect on taste of final product.
Similar to previous study, the glutamic acid was the high quality in the H. scabra (Omran, 2013, Sroyraya et al., 2017), $H$. arenicola and $A$. mauritiana (Haider et al., 2015; Omran, 2013), H. tubulosa and H. polii (Sicuro et al., 2012), B. marmorata and H. leucospilota (Omran, 2013).

The combination or proportion of amino acid is a great importance. For example, in the previous study suggested that lower lysine/arginine ratio $(0.67)$ has been reported as hypercholesterolemic and antiatherogenic effects (Rajamohan \& Kurup, 1997). Results obtained in this study showed that the sea cucumber $S$. vastus contains lower lysine/arginine ratio was found to be 0.14 . This was consistent with those of other sea cucumbers, namely $H$. scabra (0.13) (Sroyraya et al., 2017) and lower than that of other sea cucumbers, including $H$. tubulosa $(0.27)$ and H. polii (0.22) (Sicuro et al., 2012), A. japonicus (0.40) (Lee et al., 2012), $H$. arenicola (0.34) and $A$. mauritiana (0.44) (Haider et al., 2013), H. scabra (0.41), and H. leucospilota (0.43) (Omran, 2013). The ratio of lysine/arginine in this study was also lower than that of varieties of fish, including European sea 
Table 2. Fatty acid composition of fresh sea cucumber Stichopus vastus

\begin{tabular}{llc}
\hline No & \multicolumn{1}{c}{ Parameter } & Result (\%) \\
\hline & Saturated Fatty Acids & \\
1 & C4:0 (Butyric acid) & 0.01 \\
2 & C8:0 (Caprylic acid) & 0.01 \\
3 & C10:0 (Capric acid) & 0.01 \\
4 & C12:0 (Lauric acid) & 0.02 \\
5 & C14:0 (Myristic acid) & 0.03 \\
6 & C16:0 (Palmitic acid) & 0.07 \\
7 & C17:0 (Heptadecanoic) & 0.01 \\
8 & C18:0 (Stearic acid) & 0.02 \\
9 & C20:0 (Arachidic acid) & 0.01 \\
& Mono Unsaturated Fatty Acids & \\
10 & C16:1 (Palmitoleic acid) & 0.03 \\
11 & C18:1 w9C (Oleic acid) & 0.01 \\
12 & C24:1 w9 (Nervonic acid) & 0.01 \\
& Poly Unsaturated Fatty Acids & \\
14 & C18:2 w6C (Linoleic acid) & 0.01 \\
15 & C20:4 w6 (Aracidonic acid) & 0.13 \\
16 & C20:5 w3 (cis-5,8,11,14,17-Eicosapentanoic acid) & 0.02 \\
17 & C22:2 (cis-13,16-Docosadienoic acid) & 0.01 \\
18 & 5Saturated Fatty Acids & 0.17 \\
19 & 5Mono Unsaturated Fatty Acids & 0.05 \\
20 & 5Poly Unsaturated Fatty Acids & 0.16 \\
\hline
\end{tabular}

bass Dicentrarchus labrax, gilthead sea bream Sparus aurata and turbot Psetta maxima were $0.85,0.85$ and 0.95 respectively (Kaushik, 1998). The result of the present study and previous reports indicate that the body walls of sea cucumbers are a healthy food for people.

The composition of fatty acids in S. vastus is given in Table 1. The fatty acid composition was dominated by saturated fatty acids followed by polyunsaturated fatty acids and monounsaturated fatty acids. This result was consistent with previous study that reported saturated fatty acids as the dominant fatty acids in sea cucumber such as $S$. herrmanni, $T$. ananas, $T$. anax, $H$. fuscogilva, $H$. fuscopunctata, $A$. caerulea and $B$. argus (Wen et al., 2010), H. scabra (Sroyraya et al., 2017), Lee et al., 2012), H. leucospilota and $H$. atra (Bingham, 1977). Monounsaturated fatty acids were the dominant fatty acids in $A$. mauritiana (Wen et al., 2010), Parastichopus californicus (Gao et al., 2011), Apostichopus japonicus (Omran, 2013; FAO/ WHO,2003); whereas polyunsaturated fatty acids were dominant in $H$. leucospilota (Omran, 2013), $H$. arenicola (Haider et al., 2015), S. horrens (Lee et al., 2012), H. tubulasa and H. polii (Sicuro et al., 2012).

The major saturated fatty acid in the present study was palmitic acid $(0.07 \%)$, followed by myristic acid
$(0.03 \%)$, stearic acid $(0.02 \%)$, lauric acid $(0.02 \%)$, caprylic acid $(0.01 \%)$, butyric acid $(0.01 \%)$ and arachidonic acid $(0.01 \%)$. Similarly in the previous study, palmitic acid was the major saturated fatty acid in Thelenota anax, $H$. fuscogilva, $H$. fuscopunctata, A. caerulea and B. argus (Wen et al., 2010), $A$. japonicus (FAO/WHO, 2003). In other species, stearic acid was the major saturated fatty acid in S. hermanni, $T$. ananas and $A$. mauritiana (Wen et al., 2010), $H$. tubulosa (Sicuro et al., 2012), S. regalis (Santos et al., 2015) as well as $H$. edulis and H. scabra (Kidd, 2007). Palmitic acid showed antioxidant and antiatherosclerosis activities, whereas myristic acid plays an essential role in the activation of cellular functions such as signal transduction and constitutive proteins (Omran, 2013). Myristic acid showed ability to acylate proteins in a reaction which is called $\mathrm{N}$-terminal myristoylation (Beauchamp, Rioux, \& Legrand, 2009).

The major polyunsaturated fatty acid in the present study was arachidonic acid $(0.13 \%)$ followed by cis-5,8,11,14,17-Eicosapentanoic acid (0.02\%), cis13,16-Docosadienoic acid (0.02\%) and linoleic acid $(0.01 \%)$. Similarly, arachidonic acid was the major polyunsaturated fatty acid in $S$. herrmanni, $T$. ananas, $T$. anax, $H$. fuscogilva, $H$. fuscopunctata, $A$. caerulea and $B$. argus and $A$. mauritiana (Wen et al., 2010). In 
A. japonicus, cis-5,8,11,14,17-Eicosapentanoic acid was the major polyunsaturated fatty acid (Gao, Xu, \& Yang, 2011), whereas cis-11,14,17-Eicosatrienoic acid was the major polyunsaturated fatty acid in $H$. tubulosa, H. polii (Sicuro et al., 2012) and H. edulis (Kidd, 2007). Arachidonic acid plays an important role in human health, especially growth because it is the main precursor of eicosanoics (Santos et al., 2015).

The major monounsaturated fatty acid in the present study was palmitoleic acid $(0.03 \%)$, followed by oleic acid $(0.01 \%)$ and nervonic acid $(0.01 \%)$. Compared to previous study, palmitoleic acid was the major monounsaturated fatty acid in $T$. ananas, $T$. anax, $H$. fuscogilva, A. caerulea, $H$. fuscopunctata (Wen et al., 2010) and H. scabra (Al Azad et al., 2017). Erucic acid was the major monounsaturated fatty acid in $S$. herrmanni, Bohadschia argus and A. mauritiana (Wen et al., 2010).

Therefore, difference species and geographic location may cause different fatty acid compositions in sea cucumbers. It is known that sea-bed sediment contains branched fatty acids derived from microorganisms and detritus of which lipid components might be accumulated in the sea cucumbers (Al Azad et al., 2017). Meanwhile, the diet, degree of maturation, water temperature, and species characteristics are the factors that affect the properties of lipids and fatty acid composition in marine animals (Yamashima, Ikejima, Rusyn, \& Sato, 2007).

The omega-3 fatty acids, docosahexaenoic acid (DHA) and eicosapentaenoic acid (EPA) are conditionally essential nutrients that may enhance quality of life, where the lowest of them risk for premature death. They function exclusively via cell membranes, in which they are anchored by phospholipid molecules. DHA is proven essential to pre- and postnatal brain development, whereas EPA seems more influential on behavior and mood (Gil, 2002). DHA was not detected in this study, whereas EPA was found as much as $0.02 \%$. In addition to being used as food, sea cucumber is used for medicinal products, such as for the treatment for asthma, hypertension, rheumatism, anemia, and sinus congestion. The tissue repairing ability of sea cucumber is strongly related with EPA (Fredalina et al., 1999).

The omega-3/omega- 6 ratio of sea cucumber $S$. vastus was 0.15 . This value was lower than that reported by Wen et al. (2010) in S.herrmanni, $T$. ananas, $T$. anax, $H$. fuscogilva, $H$. fuscopunctata, $A$. mauritiana, $A$. caerulea and $B$. argus that ranged from 0.25 to 0.61 . Based on FAO/WHO (2003) recommendation that the omega-3/omega- 6 ratio should be between 0.125 to 0.40 , thus the result of this study may contribute to maintain the recommended omega-3/omega-6 ratio in diet.

\section{Conclusion}

All essential and non-essential amino acids were found in the sea cucumber Stichopus vastus collected from Salemo Island, Indonesia. The major essential amino acid content was arginine, whereas the major non-essential amino content was glycine. The saturated fatty acids content in $S$. vastus was higher than those of polyunsaturated fatty acids and monounsaturated fatty acids. The result of this study confirmed that $S$. vastus from Salemo Island waters Indonesia is a good source of amino acid and fatty acid for human diet in the future.

\section{Acknowledgement}

The author wishes to acknowledge the financial support from the Budget Implementation Registration Form of the Research Center for Oceanography, Indonesian Institute of Sciences. The author would also like to thank to Prof. Prapto Darsono, M.Sc. for species identification.

\section{References}

Al Azad, S., Shaleh, S.R.M., \& Siddiquee, S. (2017), Comparison of fatty acid and proximate composition between Holothuria edulis and Holothuria scabra collected from coastal water of Sabah, Malaysia. Adv. Biosci. Biotechnol. 8: 91-103.

AOAC. (2000). AOAC Official Method for Analysis, Oil and Fat: 26-28.

Beauchamp, E., Rioux, V. \& Legrand, P. (2009). New regulatory and signal functions for myristic acid. Med. Sci. (Paris). 25(1): 57-63.

Bechtel, P.J., Oliveira, A.C.M., Demir, N. \& Smiley, S. (2013). Chemical composition of the giant red sea cucumber Parastichopus californicus, commercially harvested in Alaska. Food Sci. Nutr. 1(1): 63-73.

Bingham, S. (1977). Dictionary of nutrition: a consumer guideto the fact of food. Barrie \& Jenkins,London, United Kingdom :319 p.

FAO/WHO. (1990). Report of the joint FAO/WHO expert consultation of protein quality evaluation. Bethesda, MD.

FAO/WHO. (2003). Diet, nutrition and the prevention of chronic disease. Technical Report Series 916. Food and Agriculture Organization/World Health Organization, Geneva

Fredalina, B.D., Ridzwan, B.H., Abidin, A.A.Z., Kaswandi, M.A., Zaiton, H., Zali, I., Kittakoop, P. \& Jais, A.M.M. (1999). Fatty acid compositions in local sea 
cucumber, Stichopus chloronotus, for wound healing. Gen. Pharmacol. 33(4): 337-340.

Gao, F., Xu, Q., \& Yang, H. (2011). Seasonal biochemical changes in composition of body wall tissue of sea cucumber Apostichopus japonicas. Chin. J. Oceanol. Limnol. 29(2): 252-260.

Gil, A. (2002). Polyunsaturated fatty acids and inflammatory disease. Biomed. Pharm. 56: 388-396.

Haider, M.S., Sultana, R., Jamil, K., Zehra, L., Tarar, O.M., Shirin, K. \& Afzal, W. (2015). A study on proximate composition, amino acid profile, fatty acid profile and some mineral contents in two species of sea cucumber. J. Anim. Plant Sci. 25(1): 168-175.

Kaushik, S. (1998). Whole body amino acid composition of European seabass (Dicentrarchuslabrax), gilthead seabream (Sparus aurata) and turbot (Psetta maxima) with an estimation of their IAA requirement profiles. Aquat. Living Resour., 11: 355-358.

Kidd, P.M., (2007), Omega-3 DHA and EPA for cognition, behavior, and mood: clinical findings and structuralfunctional synergies with cell membrane phospholipids, Altern. Med. Rev., 12(3), 207-227.

Lee, M.H., Kim, Y.K., Moon, H.S., Kim, K.D., Kim, G.G., Cho, H.A. Yoon, N.Y. Sun, K.B., Park, H.Y. Lee, D.S. Lim, C.W., Yoon, H.D. \& Han, S.K. (2012). Comparison on proximate composition and nutritional profile of Red and Balck sea cucumbers (Apostichopus japonicas) from Ulleungdo (Island) and Dokdo (Island), Korea. Food Sci. Biotechnol. 21(5): 12851291.

Lovatelli, A. \& Conand, C. (2004). Food and Agriculture Organization of the United Nations. Advances in sea cucumber aquaculture and management, FAO fisheries technical paper United Nations Food \& Agriculture Org. 463: 58.

Omran, N.E.E. (2013). Nutritional value of some Egyptian sea cucumber. Afr. J. Biotechnol. 12(35): 5466-5472.

Penha-Lopes, G., Torres, P., Narciso, L., Cannicci, S. and Paula, J. (2009). Comparison of fecundity, embryo loss and fatty acid composition of mangrove crab species in sewage contaminated and pristine mangrove habitats in Mozambique. Journal of Experimental Marine Biology and Ecology. 381: 2532.

Preston, G. (1993). Beche-de-mer. In: Nearshore Marine Resources of the South Pacific: Information for
Fisheries Development and Management. Wright, A. \& Hill, L. (eds). Honiara, Forum Fisheries Agency: 371-407.

Rajamohan, T., \& P.A. Kurup. (1997). Lysine: arginine ratio of a protein influences cholesterol. J. Exp. Biol. 35: 1218-1223.

Ridzwan, B.H., Hanita, M.H., Nurzafirah, M., Norshuhadaa, M.P.S., \& Hanis, Z.F. (2014). Free fatty acids composition in lipid extracts of several sea cucumber species from Malaysia. Int. J. Biosci. Biochem. Bioinforma. 4(3): 204-207.

Santos, R., Dias, S., Pinteus, S., Silva, J., Alves, C., Tecelao,C., Pombo, A., \& Pedrosa, R. (2015). The biotechnological and seafood potential of Stichopus regalis. Adv. Biosci. Biotechnol. 6: 194-204.

Sicuro, B., Piccinno, M., Gai, F., Abete, M.C., Danieli, A., Dapra, F., Mioletti, S., \& Vilella, S. (2012). Food quality and safety of Mediterranean sea cucumber Holothuria tubulosa and Holothuria polii, Asian J. Anim. Vet., 7(9): 851-859.

Siddiqui, Y.D., Arief, E.M., Yusoff,A., Suzina, A.H. \& Abdullah, S.Y. (2013). Isolation of pepsin-solubilized collagen (PSC) from crude collagen extracted from body wall of sea cucumber (Bohadschia spp.). Int. J. Pharm. Pharm. Sci., 5(2): 555-559.

Sroyraya, M., Hanna, P.J., Siangeham, T., Tinikul, R., Jattujan, P., Poomtong, T. \& Sobhon, P. (2017). Nutritional composition of the sea cucumber Holothuria scabra. Functional Foods in Health and Disease. 7(3): 168-181.

Venugopal, V. (2008). Marine products for healthcare: functional and bioactive nutraceutical compounds from the ocean, CRC press: $328 \mathrm{p}$.

Waters. (2012). Acquity UPLC H-Class an H-Class Bio Amino Acid Analysis System Guide. USA.

Wen J., Hu, C. \& Fan, S. (2010). Chemical composition and nutritional quality of sea cucumber. J. Sci. Food Agric. 90: 2469-2474.

Yahyavi, M., Afkhami, M., Javadi, A., Ehsanpour, M., Khazaali, A., Khoshnood, R., \& Mokhlesi, A. (2012). Fatty acid composition in two sea cucumber species, Holothuria scabra and Holothuria leucospilota from Qeshm Island (Persian Gulf). Afr. J. Biotechnol., 11(12): 2862-2868

Yamashima, S., Ikejima, K., Rusyn, I., \& Sato, N. (2007), Glycine as a potent anti-angiogenic nutrient for tumor growth, J. Gastro. Hepato. 22(1): 62-64. 